\title{
A LIBERDADE DE EXPRESSÃO E OS PRINCÍPIOS PUBLICITÁRIOS CONSUMEIRISTAS: UMA RELEITURA NECESSÁRIA À PROTEÇÃO DA CRIANÇA E ADOLESCENTE
}

\section{FREEDOM OF EXPRESSION AND CONSUMER LAW: A RELEASE REQUIRED TO PROTECT CHILDREN AND ADOLESCENTS}

\author{
${ }^{1}$ Carla Fernandes de Oliveira \\ ${ }^{2}$ Saulo Bichara Mendonça
}

\section{RESUMO}

A liberdade de expressão está relacionada ao potencial humano de desenvolver pensamentos, formar opiniões, estabelecer ideias e ideais, explorar uma capacidade mental e cognitiva. Mister se faz a análise da sua natureza e limites no que tange ao âmbito do exercício na seara empresarial e contratual, perquirindo se a liberdade de expressão empresarial relaciona-se à publicidade de ofertas de bens e serviços de consumo a uma determinada parcelada da sociedade composta por um público infantil e adolescente, verificando se o exercício da liberdade de expressão associada à publicidade empresarial trata-se de um direito fundamental.

Palavras-chaves: Equidade; Liberdade de Expressão Empresarial; Limites de Direitos Fundamentais; Publicidade; Público Infantil e Juvenil.

\begin{abstract}
Freedom of expression is related to the human potential to develop thoughts, form opinions, to establish ideas and ideals, exploring a mental and cognitive ability. Imperious is made the analysis of its nature and limits with respect to the exercise in business and contractual harvest, inquiring if the freedom of business expression is related to the advertising of goods offerings and consumer services to a particular split of society composed by a child and adolescent public, ensuring that the exercise of freedom of expression associated with business advertising it is a fundamental right.
\end{abstract}

Keywords: Equity; Freedom of Expression; Limits of Fundamental Rights; Advertising; Child and Youth Public.

\footnotetext{
${ }^{1}$ Professora Assistente pela Universidade Federal Fluminense - UFF, Rio de Janeiro (Brasil). Doutoranda pela Universidade Estácio de Sá - Estácio, Rio de Janeiro (Brasil). E-mail: fernandescarla@id.uff.br

${ }^{2}$ Professor Adjunto II pela Universidade Federal Fluminense - UFF, Rio de Janeiro (Brasil). Pós - doutorando pela Universidade do Estado do Rio de Janeiro - UERJ, Rio de Janeiro (Brasil). E-mail: saulobmendonca@live.com
} 


\section{Introdução}

Tendo a liberdade de expressão como princípio constitucional atrelado ao potencial humano de desenvolver pensamentos, raciocinar, formar opiniões, estabelecer ideais, explorar a capacidade mental e cognitiva, intimamente, pautada na racionalidade e na necessidade de propagar ideias, verifica-se a necessidade de refletir sobre a forma como a comunicação se materializa, a fim de que o exercício deste direito não venha inferir negativamente na esfera de direitos alheios, em especial de pessoas não dotadas de capacidade plena, menores impúberes, carentes de proteção especial no momento de formação do caráter e da personalidade.

O raciocínio que ora se pretende desenvolver possui justificativas filosóficas, sociológicas e econômicas, mas terá como viés fundamental as razões de ordem jurídica que pautam o debate acerca da liberdade de expressão, analisada por sua natureza constitucional que, apesar de lhe atribuir status de princípio não lhe retira limites para o seu exercício.

O contexto da análise que se propõe considera a atividade do marketing empresarial, reconhecendo o intuito de lucro do empresário empreendedor como a função social da empresa, pretende-se perquirir se as ações de propaganda e divulgação carecem de regulação ante a incapacidade relativa de adolescentes que impõe um dever de proteção a todos os cidadãos em sociedade?

Assim, parte-se da hipótese de que, na seara empresarial, a liberdade de expressão com a qual o marketing se desenvolve, promovendo a publicidade de ofertas de bens e serviços de consumo a determinadas parcelas da sociedade, em especial, no caso deste estudo, ao público infantil e adolescente, deve ser regulado a fim de proteger as características naturais dos seres humanos nesta faixa etária, impedindo o amadurecimento precoce, a sensualização e a sexualização infantil e a deturpação do caráter das crianças e adolescentes, em formação.

O presente estudo se justifica pelo intuito de contribuir para a discussão acerca dos limites morais que devem ser considerados no exercício do direito à liberdade de expressão associada à publicidade empresarial, seja geral ou específica em relação aos objetos mencionados.

Esta proposta de estudo tem por objetivo revisitar o conceito de direito fundamental a fim de analisar possíveis resultados jurídicos advindo de determinada forma de comunicação, 
eventualmente realizada de maneira massificada, objetivando o convencimento de um maior número de pessoas, neste caso específico de crianças e adolescentes, ao consumo de determinado produto ou serviço.

Ressalta-se, enquanto marco teórico, o leading case gerado pela Ação Civil Pública promovida pelo Ministério Público de São Paulo em face da empresa Pandurata, detentora da marca Bauducco, em 2007. Em síntese, a aduzida demanda tinha como razão a discussão se uma determinada publicidade feita pela parte Ré, para atingir diretamente o público infantil, seria abusiva e estaria valendo-se da vulnerabilidade e ingenuidade das crianças, por essa razão teria incentivado o consumo exagerado de alimentos excessivamente açucarados. Ademais, também havia o questionamento de que a publicidade teria utilizado comandos imperativos e a prática de venda casada, ao condicionar a obtenção de relógios à compra dos produtos alimentícios ofertados. A ação teve seu julgamento final julgada favorável à pretensão autoral, em sede de recurso, pela $2^{\text {a }}$ Turma do Superior Tribunal de Justiça, em junho de 2016, trazendo apreciação impactante sobre o tema, apresentando uma decisão que pode ter constituído uma regra importante, criando um precedente para casos futuros.

\section{O princípio da publicidade na relação consumeirista}

Os fornecedores de bens e produtos necessitam ofertá-los ao público alvo, com o fito principal de não só despertar interesse nos consumidores em potencial mas, também, e principalmente, de convencê-los à aquisição efetiva e fidelização futura. $O$ consumo conquistado com êxito consiste em prática fundamental para que os fornecedores desenvolvam suas atividades empresariais, comerciais e industriais e atinjam seus objetivos e lucros e crescimento no mercado.

Alguns produtos e serviços ligados às necessidades básicas do indivíduo e de sua família (alimentação voltada à cesta básica, vestimentas mínimas e serviços de energia elétrica, gás e água, por exemplo), dispensam uma maior e mais definida divulgação. Todavia produtos e serviços mais caros, raros ou seletivos (alimentação e serviços que ultrapassam as necessidades básicas, vestimentas de grife, dentre outros) carecem de uma publicidade mais imponente e, às vezes, agressiva de marketing; principalmente se levarmos em consideração aspectos de competitividade a nível mundial, seja no mundo físico, seja no mundo cibernético. 
Com a entrada em vigor no Brasil do Código de Defesa do Consumidor ${ }^{3}$ percebe-se que uma grande proteção ao consumidor, em uma sociedade capitalista contemporânea, se demonstra cogente. Um dos primeiros pontos pode estar atrelado ao rompimento com uma herança histórica e secular no tratamento normativo inerente às relações de consumo, em que a lei civilista outrora orientava os mais variados contratos, inclusive os consumeiristas, sem analisar suas particularidades e diferenças sensíveis, tornando imperioso o surgimento de uma lei especial pudesse tratar de relações de consumo que de paritárias nada possuíam. Há uma série de características que os contratos de consumo possuem que exigem do intérprete da norma uma visão diferenciada.

Outro aspecto na relação de consumo reflete a minuciosa atenção aos princípios e sua adequada aplicabilidade, interpretação das cláusulas contratuais (geralmente compondo contratos de adesão), publicidade nas ofertas e responsabilidade dos fornecedores impostos pelo Código de Defesa do Consumidor. As partes contratantes não dispõem das mesmas condições de forças; destarte não se pode aplicar tão somente princípios civilistas como autonomia da vontade e pacta sunt servanda acreditando que seria suficiente para dirimir conflitos e atingir um bem comum à sociedade.

Outros princípios devem ser levados em consideração: boa fé objetiva, probidade, função social dos contratos, vulnerabilidade do consumidor, direito do consumidor à informação, proteção e publicidade que reproduza uma análise sistemática de todo o tratamento fático, normativo e principiológico imposto pelo Código de Defesa do Consumidor, enquanto lei especial.

Se levado em consideração que a publicidade na relação de consumo é um grande pilar que pode gerar o interesse do consumidor, esse momento impõe uma regra de conduta proba e correta aos fornecedores de bens e produtos que, ao utilizar um meio para divulgar suas ofertas, não podem se valer de meias verdades ou, pior, de falsas verdades.

A publicidade representa uma verdadeira origem do interesse do consumidor. Razão pela qual é preciso analisar, dentro de cláusulas gerais, se tal publicidade está adstrita a regras

\footnotetext{
${ }^{3}$ Lei $n^{\circ} 8.078$, de 11 de setembro de 1990 , que dispõe sobre a proteção do consumidor e dá outras providências. O lapso temporal entre a publicação desta norma infraconstitucional e a sua entrada em vigor (vacatio legis) foi cento e oitenta dias a contar de sua publicação, para que a população como um todo pudesse verificar as importantes diferenças de se analisar e interpretar um contrato de caráter particular ou mercantil, que em regra possui como base normativa o Código Civil, com um contrato de consumo que envolve fornecedores de bens e serviços e consumidores, possuindo após a lei em comento legislação especial, apenas se podendo aplicar a regra geral de forma subsidiária e não colidente.
} 
de mercado livre ou se possuem limites principiológicos, sob pela de ser considerada enganosa ou abusiva.

A técnica legislativa no Brasil, principalmente no curso do século XX, passou a utilizar-se de cláusulas abertas ou conceitos indeterminados. Deixando, muitas vezes, aberto o comando normativo primitivo e, com isso aberta também, suas possíveis consequências jurídicas. Impondo ao intérprete um importante papel decisório: valer-se dos parâmetros fornecidos pelo legislador que devem ser aplicados conforme os elementos apresentados no caso concreto; atribuindo ao interprete uma função integradora da norma, valorando-a.

Na sequiência histórica, sobreveio a ascensão dos princípios, cuja carga axiológica e dimensão ética conquistaram, finalmente, eficácia jurídica e aplicabilidade direta e imediata. Princípios e regras passam a desfrutar do mesmo status de norma jurídica, sem embargo de serem distintos no conteúdo, na estrutura normativa e na aplicação. (BARROSO, 2004, p.03)

É presumível que se tenha percebido que é absolutamente impossível criar regras de subsunção em termos civilistas e, especialmente, de consumo para todas as situações concretas do cotidiano, capazes de regular acordos de vontades no ato de contratar. Da mesma forma, inaceitável imaginar que as regras poderiam ter o condão de regular todos os elementos ou pressupostos para que a publicidade, em sede de consumo, atendesse aos ditames principiológicos exigidos.

A Publicidade ${ }^{4}$, enquanto meio de ligação entre os fornecedores de bens e produtos e o consumidor, ingressa no contexto legal como um princípio capaz de nortear a conduta de quem a utiliza, possivelmente impondo limites e exigindo uma interpretação ao caso concreto.

\footnotetext{
${ }^{4}$ Não há um consenso, mesmo levado em consideração o entendimento dos especialistas em Direito do Consumidor, sobre a delimitação exata entre os termos publicidade e propaganda. Qual seria a terminologia correta em termos consumeiristas ou se inexiste diferença jurídica entre os vocábulos aduzidos. Não obstante não seja este o foco desta pesquisa; sobre o tema, apenas ilustrando, coloca-se à favor de vocábulos sinônimos quanto à aplicabilidade no ramo consumeirista: "Costuma-se usar o vocábulo 'publicidade' algumas vezes como espécie de 'propaganda'; noutras, a palavra 'propaganda' é reservada para a ação política e religiosa, enquanto 'publicidade' é utilizada para a atividade empresarial etc. Mas não há razões para a distinção. (...)Ambos os termos, portanto, seriam bastante adequados para expressar o sentido buscado pelo anunciante de produto ou serviço". (NUNES, 2010, p. 106). No sentido contrário, em que a propaganda teria como objetivo a difusão de uma idéia ou de uma ideologia e a publicidade finalidade de divulgar comercialmente um produto ou um serviço: propaganda é "toda forma de comunicação, voltada ao público determinado ou indeterminado, que, empreendida por pessoa física ou jurídica, pública ou privada, tenha por finalidade a propagação de idéias relacionadas à filosofia, à política, à economia, à ciência, à religião, à arte ou à sociedade". (NUNES JUNIOR, 2001, p. 16). O termo publicidade nesse artigo se deve não ao debate das teses acima mencionadas, muito embora relevante a discussão, mas à nomenclatura mais utilizada no Código de Defesa do Consumidor.
} 


\section{O abuso de direito e a publicidade nas relações de consumo}

O modelo do Estado Absolutista foi caracterizado por privilégios de poucos, principalmente séculos XV a XVIII, e acabou gerando a possibilidade da aplicabilidade da teoria do ato emulativo que possuía um único propósito: satisfazer aos interesses próprios de quem praticava esses atos sob o (pseudo)manto do exercício de um direito reconhecido, com um objetivo único de prejudicar ao outro. Assim, o ato emulativo seria um ato sem utilidade alguma para o agente que o faz, no intuito de prejudicar terceiro. Muito embora a existência dessa teoria é bem verdade que há muito se repudia o agir daquele que se serve de um direito apenas, e tão somente, para prejudicar outrem.

A teoria do ato abusivo embora tenha sido construída ao longo do século XX, possui sua origem ligada ao Direito Medieval. Os atos praticados com a íntima e direcionada intenção de causar prejuízo a terceiros eram vistos como atos emulativos e tinham relação direta com o direito de propriedade e com os direitos de vizinhança, num primeiro momento.

A vida medieval continha uma rotina propícia para o propósito que envolvia o ato abusivo: a apatia e atrofia da atuação do Estado no que concerne a defesa dos direitos coletivos, as constantes brigas entre vizinhos, o natural uso da força na conquista de direitos, os confrontos que envolviam questões de poderes e discussões ligadas às classes dominantes e às corporações, dentre outros fatores.

O Direito Romano no que tange ao caráter individualista do direito de propriedade no Direito Romano, por exemplo, (GONÇALVEZ, 2015, p. 244); o Direito Francês e a existência de uma expressiva feição individualista, nesta fase oriunda das ideias liberais, pós Revolução Francesa. (GONÇALVEZ, 2015, p. 244) e o Direito Alemão (SÁ, 2005, p. 61-63), por exemplo, trazem na sua história resquícios dos atos emulativos, haja vista que eram praticados os atos mais abrasivos, completamente abusivos, com o firme propósito de se exercitar um direito reconhecido por lei. Isto reflete uma das mais antigas ideias do ser humano de que aquilo que não estivesse proibido em escala privatista seria, então, permitido.

Havia um vácuo a ser preenchido.

Uma infeliz lacuna que concedia, em tese, a prerrogativa ao titular um direito para exercê-lo com o objetivo de prejudicar a terceiro. Atualmente, temos a real consciência de que nem tudo que não é proibido é, necessariamente, permitido, eis que a lacuna entre o permitido e o proibido encontra-se hoje preenchida pelo ato abusivo (CARPENA, 2001, p. 37 e 38). 
Não obstante o Direito Romano, Francês e Alemão apresentarem uma visão complacente aos atos abusivos, como uma consequência natural do exercício de um direito absoluto ou não proibido pela Lei, à luz da vedação dos atos emulativos, aqueles amparados pelo manto da teoria do abuso do direito, começaram, mesmo que timidamente, por mitigar, relativizar, os referidos abusos.

Destacamos no Direito Romano a possibilidade de perda da propriedade quando o titular se recusava a prestar caução de dano infecto e a vedação imposta ao proprietário de que este não poderia demolir a sua casa para a alienação dos bens móveis. No Direito Alemão, decisão judicial garantiu ao filho, verdadeiro desafeto do próprio pai, o direito de adentrar nas terras do genitor, mesmo contra a sua vontade, em dias de festa, para poder prestar homenagens a mãe falecida e ali enterrada.

Finalmente, e não menos importante por isto, no Direito Francês nos deparamos com o célere caso Clement Bayard, julgado pela Corte de Amiens, que teve como decisão o reconhecimento de ser abusiva a conduta do proprietário que, sem a menor justificativa plausível e aceitável, decidiu por construir enormes torres com lanças pontiagudas de ferro em direção ao firmamento com um único propósito: furar os dirigíveis de um terceiro que utilizavam um terreno confrontante como local de pouso e decolagem. Os direitos de vizinhança correspondem a um tema que contribuiu ao debate jurídico do abuso de direito e teoria do (e da vedação ao) ato emulativo. (CARDOSO, 2006, p. 63).

A decisão histórica, dentro de um Estado que via no direito de propriedade um verdadeiro campo sem ligação direta com o campo público e coletivo, cujas regras privatistas encontravam-se reguladas a serviço de uma classe dominante econômica e politicamente após a revolução francesa de 1789, é um verdadeiro presságio que a abusividade no exercício de um direito não deve ser considerado um ato normal e condizente com parâmetros legais.

Dentro deste contexto e evolução históricos, com influência direta do modelo envolvendo a repartição, separação e independência envolvendo as três funções típicas do Estado - Poder Legislativo, Executivo e Judiciário - exercidas com base no sistema de freios e contrapesos e com a eclosão do movimento constitucionalista, voltado às liberdades públicas, direitos e garantias fundamentais do cidadão, com expressa interferência à forma, estrutura e organização do Estado, há uma busca paulatina no tocante à limitação do poder do Estado e seus governantes, objetivando (dentro de outras situações) afastar ou inibir ao máximo o arbítrio estatal. 
O Estado Absolutista e o próprio Estado Liberal, em seu nascedouro, crescimento e expansão, não atendiam aos interesses e aspirações dos governados principalmente em sede de Direito Privado e, mais recentemente no Brasil, em sede de Direito do Consumidor. Se aquele interferia sensivelmente nas relações contratuais, obrigacionais e de convivência em sociedade, com muita ou total ingerência do Estado em face de seus súditos, sem quaisquer garantias de direitos e com uma imensa carga de privilégios reais concedidos para a mantença da ordem jurídica em vigor; neste havia pouca ou quase nenhuma norma cogente que pudesse frear os interesses da classe burguesa e seus abusos privados, valendo a máxima que - no Estado Liberal - tudo que a lei privada não proibisse seria, em tese, permitido.

Destarte, os modelos estatais, citados anteriormente, deixavam uma enorme lacuna na efetivação de direitos. A busca pelo Estado de Direito, do Estado do Bem-Estar Social e do Estado Social de Direito apresenta seus alicerces na preocupação com os modelos herméticos positivistas, na falsa ilusão e pretensão de que as relações pragmáticas em sociedade teriam sempre uma relação de subsunção à norma, na inconformidade das classes menos protegidas em face aos abusos estatais, no combate ao individualismo exacerbado.

Por essa razão o movimento constitucional, em especial no final do século XX no Brasil, deixa sua marca dentro de uma visão socializadora de direitos com a Constituição Federal de 1988 positivando valores fundamentais, princípios basilares como a dignidade da pessoa humana, igualdade substancial, imposição da função social da propriedade, relativização de direitos subjetivos e aplicabilidade de normas de otimização.

Um novo viés constitucional passa a interferir nas relações em sociedade. Essa valoração do indivíduo reflete no direito privado. $\mathrm{O}$ centro de proteção positivada passa do patrimônio para o indivíduo. O ter sucumbe ao ser e os direitos privados, antes exercidos de forma absoluta, passam por uma nova análise de legitimidade, impondo-se o respeito aos direitos individuais do outro.

Dentro desta análise bem reduzida é possível verificar a interferência direta das nuances constitucionais no Direito Civil brasileiro e no tratamento do chamado abuso de direito (antes e depois da Constituição chamada cidadão de 1988). Dois diplomas legais civilistas e o Código de Defesa do Consumidor tratam de forma completamente distinta a noção de abuso de direito enquanto exercício (a)normal de um direito posto: o Código Civil brasileiro de 1916, extremamente baseado nas ideias liberais pós revolução francesa, com enorme carga patrimonialista e pouco interferência estatal nas relações privadas; e o Código 
de Defesa do Consumidor e o Código Civil de 2002, sustentados por paradigmas principiológicos e com relação direta a um Estado, pelo menos, de Direito.

A questão que envolve o abuso do direito sob a égide do Código Civil de 1916, revogado desde janeiro de 2003, não recebeu do legislador infraconstitucional, à época, uma atenção mais direcionada - ao contrário do que ocorreu em outros ordenamentos jurídicos, como o direito alemão, por exemplo.

No lugar de comandos positivos, o direito brasileiro optou por uma referência negativa, ou seja, uma interpretação a contrario sensu do artigo 160, inciso I do Código Civil de 1916 que tratava dos atos não considerados ilícitos. A parte final do inciso aduzido versava que o exercício regular de um direito reconhecido não constituía ato ilícito. Utilizando uma interpretação lógica, chegávamos ao entendimento de que se o exercício do direito se operava de forma não regular, de maneira distorcida, em situação que não guardava consonância com o mandamento legal deixava de ser considerado lícito e passava a apresentar um caráter de ilicitude.

À época, não se pode descartar a informação que até a entrada em vigor do Código de Defesa do Consumidor no início da década de 90 a norma que regulava as relações de consumo era o Código Civil. Destarte, tudo que a lei geral civilista não proibia, era permitido nas publicidades voltadas ao consumo.

Não era incomum verificar publicidade de bebidas alcoólicas e cigarros com lindas e jovens mulheres (as vezes até adolescentes, ou com biótipo aproximado) em belas paisagens, muitas vezes na prática de esporte induzindo uma vida saudável, feliz, e sem problemas colaterais de saúde que poderiam ser causados pelos produtos ofertados; brinquedos para crianças, que na prática eram inertes e estáticos, se apresentavam com movimentos irreais; crianças tentando hipnotizar seus pais ou responsáveis para conseguir um determinado produto comestível a base de chocolate, dentre outros exemplos. Analisados na atualidade seriam práticas publicitárias raras e/ou reprováveis.

O abuso do direito, por uma visão sistemática, estaria presente no nosso direito pátrio, antes da vigência do atual Código Civil, por uma indicação negativa e não por um comando expresso positivamente. Daí a crítica. Chegava-se ao raciocínio demonstrado através de uma visão lógica, pela visão sistemática da ciência do Direito, que nos permite perceber que, em um ordenamento constituído de regras positivadas e princípios norteadores, cada 
disposição legal é parte de um todo, não podendo, assim, visualizar a regra sem que se conheça o sistema que ratifica, ampara e solidifica esta norma em um determinado momento.

"De modo que não se tem uma boa interpretação se conduz ao vago, ao contraditório e ao absurdo, porquanto a inteligência deve encontrar sentido no que se faz" ( RIZZARDO, 2007, p. 06). A lição de Arnaldo Rizzardo dá sentido ao já afirmado e associa a boa técnica interpretativa, de um texto ou dispositivo, uma razoabilidade que pode levar ao exegeta uma melhor compreensão do dizer legal.

A ausência de comando normativo expresso quanto à teoria do abuso do direito, antes da publicação do vigente do Código de Defesa do Consumidor e do Código Civil brasileiro, não impediu que a doutrina enfrentasse o tema ${ }^{5}$ (LUNA, 1959, p. 59). Até porque quando se fala em abusos, se verificam excessos.

\begin{abstract}
No vocábulo abuso encontramos sempre a noção do excesso; o aproveitamento de uma situação contra pessoa ou coisa, de maneira geral. Juridicamente, abuso de direito pode ser entendido como o fato de se usar o poder, de uma faculdade, de um direito ou mesmo de uma coisa, além do que razoavelmente o Direito e a sociedade permitem. (VENOSA, 2013, p. 564).
\end{abstract}

A interpretação dada ao artigo 160 do Código Civil de 1916, relacionando-o a uma previsibilidade negativa da existência da teoria do abuso do direito no nosso ordenamento, impondo uma verdadeira "condenação" ao uso abusivo de um direito por seu titular, também se aplica a outros dispositivos do Código Civil revogado.

É imperioso afirmar que sob a égide do Código Civil de 1916, e antes da vigência da lei especial que dispõe sobre as relações de consumo, não havia que se falar em análise da eticidade e valoração do abuso do direito de forma direta. Não se expressava a ideia de diferenciação entre o campo da abusividade e da ilicitude, relacionava-se, tão somente o abuso do direito a este último de forma estrita. É nesta seara da ilicitude que se aplicava a hermenêutica de que a um ato praticado pelo titular de um direito de forma irregular, anormal, ultrapassando os limites deste próprio direito abusivamente estaria cometendo, na esfera cível, simplesmente, um ato ilícito.

Com o reconhecimento da teoria do abuso do direito, e a necessidade social e jurídica de afastar tais atos mesmo dentro de uma aplicabilidade mais simplória e uma análise mais restrita, passou-se a relativizar um direito considerado deveras absoluto. Inicia-se, por conseguinte, com estes mencionados exemplos uma tímida discussão da função social dos

\footnotetext{
${ }^{5}$ Everaldo da Cunha Luna expõe que no abuso de direito a conduta humana é repudiada em virtude de um juízo de valor.
} 
direitos, ou seja, o não proprietário (não titular de direitos) sofredor dos efeitos do ato abusivo e do prejuízo arcado, passa a exigir a liberdade de questionar a antijuricidade do ato abusivo: “em síntese, o ato abusivo está situado no plano no plano da ilicitude, mas com o ato ilícito não se confunde, tratando-se de categoria autônoma da antijuricidade". (TEPEDINO, 2003, p.381).

Ainda sobre o tema, é possível afirma que no abuso de direito "alguém aparentemente atua no exercício de um direito subjetivo. $\mathrm{O}$ agente não desrespeita a estrutura normativa, mas ofende sua valoração". (FARIAS; ROSENVALD, 2011, p. 180).

O Código de Defesa do Consumidor e o Código Civil brasileiro de 2002, em vigência na contemporaneidade, são visivelmente caracterizados com a aplicabilidade de princípios e de cláusulas gerais. Justifica-se tal técnica legislativa jurídica, empregando-se signos que garantem um sistema aberto, permitindo a evolução interpretativa e teleológica da ordem jurídica de acordo com os padrões culturais e éticos da sociedade.

É o oposto do sistema hermético positivista. Nesse novo sistema, os operadores do direito possuem, inegavelmente, um papel atuante na aplicabilidade e no sentido funcional das normas jurídicas ao caso concreto. Nesse sentido leciona Gerson Luiz Carlos Branco: "A grande modificação na linguagem do novo Código Civil foi a sua projeção para o futuro, que pode ser vista pela edição de normas abertas, cláusulas gerais e conceitos jurídicos indeterminados localizados estrategicamente” BRANCO, 2002. p. 24).

O Código de Proteção e Defesa do Consumidor e, posteriormente, o Código Civil em vigor trouxeram a superação da teoria do ato emulativo, pelo menos em tese, entendendo enquanto ato ilícito não apenas o originalmente ilícito desde o seu nascedouro, mas também ilegítimo o exercício de um direito quando o titular ultrapassa os limites impostos pela boa-fé, pelos bons costumes ou pelo fim social ou econômico desse direito.

Com efeito, o artigo 187 do Código Civil brasileiro dispõe que: “também comete ato ilícito o titular do direito que, ao exercê-lo, excede manifestamente os limites impostos pelo seu fim econômico ou social, pela boa-fé ou pelos bons costumes." (Grifamos).

No Código de Defesa do Consumidor se observa, mediante a simples leitura dos artigo $6^{\circ}$, inciso IV; artigo 37 caput e respectivos parágrafos e artigo 39, inciso IV que a figura do abuso do direito não se encontra revestida dos elementos subjetivos da intencionalidade do fornecedor ou de sua culpa. A inobservância gera uma responsabilidade objetiva. Haja vista que se é um direito básico do consumidor (i) "a proteção contra a 
publicidade enganosa e abusiva"; (ii) que a Lei especial proíbe "toda publicidade enganosa e abusiva"; (iii) que se trata de publicidade abusiva aquela "que se aproveite da deficiência de julgamento e experiência da criança" e aquela que "seja capaz de induzir o consumidor a se comportar de forma prejudicial ou perigosa à sua saúde ou segurança"; (iv) que é proibido ao fornecedor de produtos e serviços "prevalecer-se da fraqueza ou ignorância do consumidor, tendo em vista sua idade, saúde, conhecimento, ou condição social, para impingir-lhe seus produtos e serviços".

Essa mudança legislativa passa corrobora com correta a perspectiva objetiva do abuso do direito consagrada na súmula $127^{6}$ do egrégio Tribunal de Justiça do Estado do Rio de Janeiro e também no enunciado $n^{\circ} 37^{7}$ do Conselho da Justiça Federal (STJ), forçoso reconhecer que pode existir comportamento abusivo em que o agente tenha o deliberado propósito de prejudicar alguém (ato emulativo) ou que, por inobservar o dever de cuidado com o outro, acabou por exercer seu direito de modo irregular.

Enfim, para que haja abuso do direito, não há necessidade de culpa ou dolo do lesante, mas tal elemento subjetivo pode existir, acarretando efeitos jurídicos importantes e, eventualmente, até mesmo a compensação por dano moral. $\mathrm{O}$ abuso do direito exige para a sua configuração a existência de um direito que é exercido em desconformidade com a finalidade social para o qual o instituto foi criado e tutelado pelo ordenamento jurídico. Esse comportamento irregular acaba por acarretar um prejuízo para alguém ou para a coletividade, como ocorre, por exemplo, na publicidade abusiva.

A natureza jurídica conferida pela lei ao ato abusivo é a de ato ilícito (artigo 187, Código Civil Brasileiro, já citado neste artigo), na sua esfera funcional, funcional. Isto é, tratase do descumprimento de um dever jurídico preexistente exigido pela função social do direito ou pela boa-fé objetiva entre as pessoas envolvidas. O efeito jurídico do abuso do direito dependerá da consequência da violação da finalidade social do direito perante a vítima.

O comportamento abusivo do titular do direito pode ensejar para o lesado, por exemplo, a retirada de circulação da publicidade abusiva nas relações de consumo, sem prejuízo da indenização pelo dano material e/ou moral, se cabíveis no caso concreto.

\footnotetext{
${ }^{6}$ Súmula 127 - "para a configuração do abuso do direito é dispensável a prova da culpa".

${ }^{7}$ Enunciado provado na I Jornada de Direito Civil, sob a presidência do Ministro Ruy Rosado de Aguiar Junior. Enunciado 37 - “Art. 187. A responsabilidade civil decorrente do abuso do direito independe de culpa e fundamenta-se somente no critério objetivo-finalístico.",
} 


\section{Limites pragmáticos e jurisprudenciais impostos à publicidade nas relações de consumo}

A concretude metodológica legislativa pode ter uma vinculação maior do intérprete à norma no sentido de subsunção da lei ao caso concreto, contudo aplica-se a uma menor quantidade de fatos. Uma vez que as situações pragmáticas em sociedade passam por inúmeras mutações e, nem sempre, a produção legal legislativa acompanha as mudanças nas relações em sociedade com a mesma rapidez e eficiência. Exige-se menos do intérprete; aplica-se menos também.

No caso das normas que compreendem em seu texto cláusulas gerais possuem um maior grau de abstração e de aplicabilidade. Desta forma, permitem ao operador do Direito maior liberdade para aplicar a norma ao caso concreto. Não há que se falar em arbítrio do julgado ou intérprete; existem limites na própria interpretação. As cláusulas gerais, geralmente, impõem que o intérprete busque o seu sentido fora do direito positivo, nas regras sociais e nas vertentes principiológicas.

A existência dessas cláusulas gerais e a aplicabilidade de conceitos indeterminados possuem uma ligação com uma interpretação teleológica, além de demais espécies. Daí sua interferência com a noção de proibição do exercício abusivo de um direito. Impondo ao intérprete um ônus maior de análise subjetiva.

Dentro desse contexto envolvendo as numeras variantes já mencionadas nesse trabalho: relações de consumo, princípio da publicidade, abusividade no exercício de um direito, regras enquanto normas de subsunção, princípios enquanto possíveis normas de otimização, existências de cláusulas gerais e conceitos indeterminados e contemporânea técnica legislativa relacionada ao Código de Defesa do Consumidor, imperioso se faz a análise de casos pragmáticos que possuam seus julgados orbitando esses temas.

Um caso concreto pode ser visto como uma decisão histórica. O Superior Tribunal de Justiça proibiu, em julgado prolatado no correte ano, publicidade dirigida às crianças em situação real ocorrida no ano de 2007. O julgamento foi da Segunda Turma do Superior Tribunal de Justiça, relativo à campanha da Bauducco denominada "É Hora de Shrek". É possível que tal decisão venha desenhar novos rumos sobre a publicidade veiculada para crianças e adolescentes, como um marco para a indústria, comércio e sociedades empresariais. 
Principalmente no sentido de que é possível afirmar que há, sensivelmente, limites à prática de ofertar produtos e serviços nas relações de consumo.

Não se trata de uma faculdade, mas de cumprimento a normas cogentes.

A Segunda Turma do Superior Tribunal de Justiça $^{8}$ entendeu por decidir como abusiva, e, consequentemente, ilegal a publicidade dirigida às crianças na campanha denominada de "É Hora de Shrek", de 2007, da empresa Pandurata, detentora da marca Bauducco. Nesta campanha publicitária, as crianças precisavam juntar cinco embalagens de qualquer produto da linha "Gulosos Bauducco", produtos que possuíam um considerável valor calórico e glicêmico, e necessitariam ainda pagar um valor agregado de R \$ 5,00 (cinco reais) para ganhar um relógio exclusivo do filme ${ }^{9}$.

Para entender o que tal publicidade, dita como promocional pela empresa ofertante, poderia gerar de interesse, principalmente nas crianças, se faz necessário dissertar sucintamente sobre o que representou a "saga" do filme Shrek nos cinemas e seus efeitos no imaginário infantil.

Vale ressaltar que o filme Shrek consistia em uma produção norte-americana de animação computadorizada, dentro gênero fantasia e comédia, tendo a princípio como público alvo crianças e adolescentes, lançado inicialmente no ano 2001. O filme foi um sucesso absoluto, tendo sido divulgado pela imprensa especializada, à época, que o primeiro filme de uma série de sucesso teria rendido uma receita de pelo menos quatrocentos e cinquenta milhões de dólares no mundo inteiro. Além da questão considerável do retorno financeiro para uma película do gênero, o filme recebeu o primeiro Oscar de melhor filme de animação e, na mesma premiação, foi indicado à melhor roteiro adaptado. Concorreu, ainda, a seis prêmios da British Academy of Film and Television Arts, incluindo o BAFTA de melhor ator coadjuvante pela interpretação de Eddie Murphy como o personagem Burro, e recebeu o BAFTA de melhor roteiro adaptado. O personagem principal recebeu uma estrela na Calçada da Fama em maio de 2010. O sucesso foi tanto que levou o estúdio a produzir três sequências: Shrek 2, Shrek the Third e Shrek Forever After, dois especiais de Natal, Shrek the Halls e

\footnotetext{
${ }^{8}$ Decisão disponível no endereço: https://ww2.stj.jus.br/processo/revista/documento/mediado/?componente=ITA\&sequencial=1495560\&num_regi stro=201500615780\&data=20160415\&formato=PDF. Acesso em 02.09.2016.

${ }^{9}$ Há ainda mais um detalhe: existiam quatro tipos de relógios diferentes, então se a criança desejasse os quatro modelos teria que adquirir 20 produtos e arcar com o custo de $\mathrm{R} \$ 20,00$ (vinte reais) de acréscimo.
} 
Scared Shrekless. O sucesso, também, inspirou outros produtos, como jogos eletrônicos, um musical e até uma revista em quadrinhos publicada pela Dark Horse Comics ${ }^{10}$.

Em suma foi um sucesso extraordinário que reinou por aproximadamente uma década de forma arrasadora. Os fornecedores de bens, produtos e serviços perceberam nitidamente a chance de lucrarem com o fenômeno chamado "Shrek"11.

O Instituto Alana, organização não-governamental que atua na área do direito à infância, denunciou a campanha ao Ministério Público de São Paulo. Para o instituto, se tratava de uma situação de venda casada, que vincula a venda e de um serviço a outro e é uma prática proibida de acordo com o Código de Defesa do Consumidor.

A questão empírica foi objeto de uma Ação Civil Pública promovida pelo Ministério Público de São Paulo que tinha por intuito demonstrar a campanha publicitária quanto a prática comercial da Bauducco foi abusiva. Em razão disso, o Ministério Público instaurou inquérito civil e tentou preliminarmente um ajustamento extrajudicial de conduta, porém tal possibilidade, na prática, se mostrou infrutífera.

Era defendido pelo Órgão do Ministério Público que a publicidade em questão era uma espécie de venda casada, conduta esta vedada pelo Código de Defesa do Consumidor. Entendia-se por venda casada dos produtos da Empresa Ré a (pseudo)promoção de aquisição de um relógio do Shrek, pela vinculação obrigatória de que a somente a compra prévia de alguns pacotes de biscoito ou bolo poderia habilitar o consumidor para a aquisição do tão desejado relógio.

Seria, então, uma estratégia publicitária que objetivava explorar a inexperiência e a deficiência de julgamento das crianças; o que, também, viola o Código de Defesa do Consumidor. A sedução de uma criança por um objeto tão "encantador" passaria a ser quase uma possibilidade nula de resistência. Ademais, os produtos condições essenciais para se tentar chegar ao tão cobiçado relógio não estimulavam a uma alimentação saudável. Muito pelo contrário. Contribuiriam, certamente, ao consumo de produtos alimentícios pobres em fibras e nutrientes saudáveis e ricos em carboidratos, gorduras e com alto valor glicêmico.

\footnotetext{
${ }^{10}$ Informações disponíveis nos endereços da internet: <http://www.cineplayers.com/filme/shrek/195>; <http://repositorio.unesp.br/bitstream/handle/11449/110597/000789151.pdf?sequence=1 >; <http://www.dreamworksanimation.com/shrek/>. Acessos em 08.09.2016.

${ }^{11} \mathrm{O}$ filme teve tanta repercussão no Brasil que até no Portal do Professor, do MEC, foi disponibilizada uma aula para explorar o filme Shrek dentro de um tema de representações do masculino e do feminino. Informação disponível em <http://portaldoprofessor.mec.gov.br/fichaTecnicaAula.html?aula=14185>. Acesso em 08.09.2016.
} 
$\mathrm{Na}$ ação civil pública, o Ministério Público pedia que a empresa fosse condenada a não mais adotar práticas comerciais que gerasse como condição a aquisição de qualquer bem ou serviço à compra de algum de seus produtos. Requeria, inclusive, pela abstenção do pólo passivo da demanda no sentido de não mais promover publicidade que, direta ou indiretamente, pudesse concorrer para a transmissão de valores inadequados a crianças, ou por qualquer modo explore sua inexperiência ou deficiência de julgamento, sob pena de multa e pela fixação de indenização em favor da coletividade difusa de consumidores, cujo valor seria revertido para o Fundo Especial de Despesa de Reparação de Interesses Difusos Lesados.

A Pandurrata, dona da Bauducco, venceu na primeira instância com a alegação de defesa que a campanha era direcionada aos pais e não às crianças, mas sucumbiu após recurso interposto no Tribunal de Justiça ${ }^{12}$. A Empresa Ré ao verificar reformada a decisão monocrática que lhe fora favorável, recorreu ao Superior Tribunal de Justiça. Através decisão da Segunda Turma, mantiveram o entendimento do colegiado do Tribunal de Justiça de São Paulo e reconheceram a campanha como abusiva de forma unânime. Eles concordaram com o argumento de que a campanha configuraria venda casada e principalmente, que o Código de Defesa do Consumidor, em seu artigo $37, \S 2^{\circ}$, a legislação classifica como abusiva qualquer propaganda que "se aproveite da deficiência de julgamento e experiência da criança".

Importante colacionar alguns trechos do voto do Ministro Herman Benjamin no Recurso Especial: 1.558.086, proferido em 10 de março do corrente ano:

\footnotetext{
Não há dúvida que este é um caso paradigmático aqui no Superior Tribunal de Justiça, porque que eu me lembre até agora, nem na seção do Direito Privado nem aqui no Direito Público onde nós amiúde examinamos questões do Direito de Consumidor, sobretudo no que se refere às autuações para os órgãos de defesa do consumidor ou mesmo quando estas questões são veiculadas por Ação Civil Pública como é este o caso.

$[\ldots]$

Nós temos uma publicidade abusiva [...] E aqui, ao contrário do que foi dito da Tribuna, não se trata de paternalismo sufocante nem de moralismo demais, é o contrário, significa reconhecer que a autoridade para decidir sobre a dieta dos filhos, é dos pais.

$[\ldots]$

Aqui, se pensarmos em termos estritamente jurídicos, é uma aberração porque criança não tem o consentimento jurídico capaz de completar o negócio jurídico, mas tem o poder de convencimento do berro a outros atos mais sutis, em supermercado, fora do supermercado; há o bullying dos outros coleguinhas, tem o
}

\footnotetext{
12 Na Apelação $n^{\text {o }}$ 0342384-90.2009.8.26.0000, a $7^{\mathrm{a}}$ Câmara de Direito Privado do TJSP acolheu por unanimidade os argumentos do Ministério Público e reformou a sentença de primeira instância que havia julgado improcedente a ação civil pública ajuizada pela Promotoria de Justiça do Consumidor da Capital por causa da campanha "É hora de Shrek", lançada pela Bauducco para promover a venda dos biscoitos "Gulosos".
} 
bullying direto dos coleguinhas que têm o relógio do Shrek, e essa pobre criança, que os pais tentam a todo custo educar ao seu modo, infelizmente, não tem.

$[\ldots]$

Mas, no momento em que nós sofremos uma crise de obesidade, aliás, todos nós brigando com o peso que insiste em não nos obedecer, mas, sobretudo às crianças, é de se espantar que uma publicidade como esta seja dirigida às crianças.

$[\ldots]$

Também não me impressiona, ainda neste primeiro ponto, um outro argumento de que milhares de anúncios são feitos, são mesmo, e por isso a necessidade do Superior Tribunal de Justiça dizer, não apenas para a Bauducco, mas para toda a indústria alimentícia, ponto final, acabou. E também não me impressiona mais um argumento de que não houve uma única reclamação, não precisa, o Código de Defesa do Consumidor no que tange à regulação da publicidade não estabelece um sistema de infração de resultado, basta a infração em si mesma, ou melhor dizendo, a prática em si mesma para caracterizar a infração.

$[\ldots]$

A hipótese é de venda casada, não há dúvida que nós temos aqui uma venda casada, e, portanto, eu estou acompanhando inteiramente, Sra. Presidente, sem mais me alongar o voto do eminente relator que eu festejo, acho, peço se a posição do relator prevalecer, que este voto, esse acórdão receba ampla divulgação, para que fiquem marcados essas duas práticas abusivas consideradas como tal pelo Código de Defesa do Consumidor. Primeiro a abusividade marcada pelo artigo $37 \S 2^{\circ}$ : publicidade de alimentos dirigida a crianças e segundo publicidade, de novo abusiva, com base no artigo 39, também do CDC por ser venda casada.

Não obstante, a decisão do Superior Tribunal de Justiça tenha efeito direto às campanhas da Bauducco, é bem verdade que a interpretação não hermética dada ao caso em virtude da hermenêutica da norma e dos princípios ao caso concreto ora relatado, de forma breve, pode influenciar em novas decisões judiciais sobre casos semelhantes, e ser um aviso às políticas de marketing das empresas e aos publicitários em geral. Ou seja: na basta ter o direito de promover publicidade de bens e produtos no mercado consumeirista; é fundamental que se analise se o exercício de um direito subjetivo provoca, ou não, ofensa a valoração da estrutura normativa.

Desta forma a decisão do Tribunal Superior reforça o entendimento doutrinário que aproveitar-se da deficiência de julgamento e experiência da criança, enquanto consumidora, gera desrespeito efetivo na medida em que viola a integridade psíquica e moral e alcança valores que não deveriam ser desrespeitados. Transgride prescrições do Código de Defesa do Consumidor (CDC) e uma vez descumprido dever jurídico originário, surge o segundo elemento que é a responsabilidade. 


\section{Considerações Finais}

Por todo o exposto é possível afirmar que o direito conferido aos fornecedores de ofertar seus produtos e serviços aos fornecedores nas relações de consumo não se trata de um direito absoluto e desprovido de análise valorativa. Alguns comportamentos e sugestões podem se valer da inexperiência da criança do adolescente na publicidade, caracterizando valores e condutas socialmente e juridicamente reprováveis.

A publicidade que estimula a manipulação das pessoas e a falsa interpretação dos comandos normativos pode ser vista como abusiva e ilícita.

Se impõe na atualidade, verificar que é possível existir uma influência negativa da propaganda no comportamento e na formação das crianças, bem como existir um liame que possa repercutir em na educação infanto-juvenil e comprometer o esforço dos pais na busca da transmissão e propagação de valores que acreditam corretos.

\section{Referências}

BARROSO, Luís Roberto. Colisão entre Liberdade de Expressão e Direitos da Personalidade. Critérios de Ponderação. Interpretação Constitucionalmente adequada do Código Civil e da Lei de Imprensa. In Revista de Direito Administrativo, Rio de Janeiro, v.235, 1-36, 2004.

BRANCO, Gerson Luiz Carlos. O culturalismo de Miguel Reale e sua expressão no novo Código Civil. In: MARTINS-COSTA, Judith; BRANCO, Gerson Luiz Carlos. Diretrizes teóricas do novo Código Civil brasileiro. São Paulo : Saraiva, 2002.

BRASIL, Constituição da República Federativa do Brasil de 1988. Disponível em: http://www.planalto.gov.br/ccivil_03/constituicao/constituicao.htm. Acesso em: 17 ago. 2016.

, Lei $\mathrm{n}^{\mathrm{o}}$ 8.078, de 11 de setembro de 1990. Disponível em: http://www.planalto.gov.br/ccivil_03/leis/18078.htm. Acesso em: 17 ago. 2016.

CARDOSO, Vladimir Mucury, O abuso do direito na perspectiva Civil-Constitucional. MORAES, Maria Celina Bodin de. (Coord.) Princípios do Direito Civil Contemporâneo. Renovar, 2006.

CARPENA, Heloisa. Abuso do direito nos contratos de consumo. Rio de Janeiro: Renovar, 2001, p. 37 e 38.

CONAR. Código Brasileiro de Auto-Regulamentação Publicitária. Disponível em: http:// www.conar.org.br. Acesso em: 17 ago. 2016. 
FARIAS, Cristiano Chaves de; ROSENVALD, Nelson. Direito dos Contratos. Editora Lumen Juris: Rio de Janeiro, 2011.

LUNA, Everaldo da Cunha. Abuso de direito. Forense: Rio de Janeiro, 1959.

NUNES JÚNIOR, Vidal Serrano. Publicidade comercial: proteção e limites na Constituição de 1988. São Paulo: Juarez de Oliveira, 2001.

NUNES, Rizzatto. Curso de Direito do Consumidor. $5^{\text {a }}$ ed. revisada, ampliada e atualizada. São Paulo: Saraiva, 2010.

RIZZARDO, Arnaldo. Parte geral do Código Civil: Lei 10.406, de 10.01.2002. $5^{\mathrm{a}}$ ed. Rio de Janeiro: Forense, 2007.

SÁ, Fernando Augusto Cunha. O abuso de Direito. Lisboa: Almedina, 2005, p. 61-63.

TEPEDINO, Gustavo. A parte geral do novo código civil. In. Estudos na perspectiva civilconstitucional / (Coord.) Gustavo Tepedino. $2^{\mathrm{a}}$ ad. Ver. E atual. Rio de Janeiro, Renovar. 2003.

VENOSA, Sílvio de Salvo. Direito Civil. Parte Geral. Editora Atlas: São Paulo, $13^{\mathrm{a}}$ edição, 2013. 